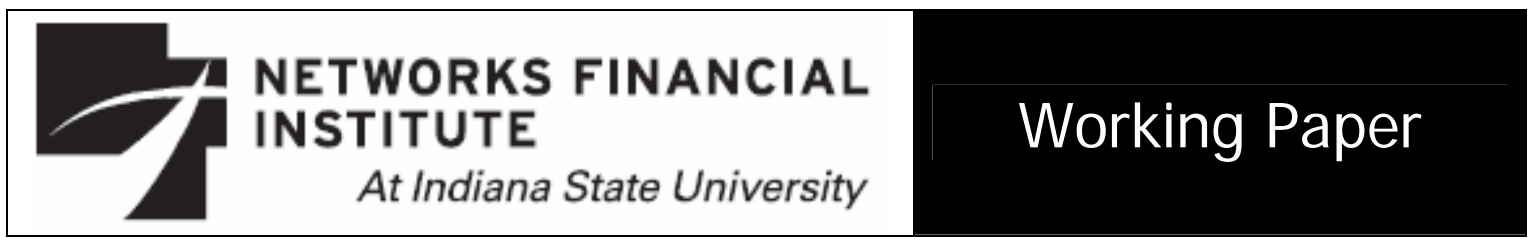

2008-WP-04

April 2008

\title{
Why Are Bank Failures Special? Lessons from U.S. Financial History Ronnie J. Phillips
}

Abstract: In the U.S., corporate bankruptcies generally go through the court system for resolution, whereas bank failures are resolved by bank regulatory agencies. The goal of corporate bankruptcy is to maximize the value of the firm as a "going concern" in liquidation to the shareholders. In a bank failure, the goal is to minimize the loss to the FDIC. The treatment of bank failures is attributed to their "special" nature that is related to their role in providing a convenient means of payment and the provisioning of credit. Additionally, the presumed contagious nature of bank failures is often cited as something that exacerbates macroeconomic problems. Though the United States is not alone in the world in its special treatment of bank failures, it does differ from many countries, most notably the United Kingdom. Since the United States is widely regarded as having an efficient financial system that has aided economic growth, this raises the question of whether there are lessons to be learned from the United States financial history. I argue that the evolution of banking in the United States was unique in that for most of its early history state chartered banks provided currency, early bank failures influenced liability insurance programs, and the role of private or unchartered banking was not important prior to the Civil War. This unique history explains why the United States evolved in the manner it did, and why the system in the United States may not necessarily be the best policy recommendation for other countries.

About the Author: Ronnie J. Phillips is a Professor of Economics at Colorado State University. Most recently he was a Scholar in Residence at the Ewing Marion Kauffman Foundation in Kansas City, Missouri and a Visiting Research Fellow at the American Institute for Economic Research in Great Barrington, Massachusetts. Previously, he has been a Visiting Scholar at the FDIC, the Comptroller of the Currency, and at the Jerome levy Economics Institute of Bard College. He is a past president of the Association for Evolutionary Economics (AFEE). His publications on financial system issues have appeared in books, academic journals, newspapers, magazines and public public poicy briefs. Philips holds a B.A. from the University of Oklahoma and a Ph.D. from The University of Texas at Austin.

Keywords: Bankruptcy, bank failures, U.S. financial history, financial institutions. J EL Classification: N21, G21

The views expressed are those of the individual author and do not necessarily reflect official positions of Networks Financial Institute. Please address questions regarding content to Ronnie J. Phillips at Ronnie.Phillips@colostate.edu. Any errors or omissions are the responsibility of the author.

This research is made possible, in part, through the support of Networks Financial Institute, an Indiana State University initiative funded through the generosity of the Lilly Endowment. 


\section{Why Are Bank Failures Special? Lessons from U.S. Financial History Ronnie J. Phillips}

\section{Introduction}

In a recent article, Bliss and Kaufman (2006) discuss how in the U.S the failures of commercial banks are treated differently from most other corporations. Corporate bankruptcies generally go through the court system for resolution, whereas bank failures are resolved by bank regulatory agencies. Presently, in the United States this federal agency is the Federal Deposit Insurance Corporation (FDIC). The two resolution regimes have different assumptions, goals, and strategies. As an example, the goal of corporate bankruptcy is to maximize the value of the firm as a "going concern" in liquidation to the shareholders. In a bank failure, the goal since the FDIC Improvement Act of 1991 is to minimize the loss to the FDIC. Though the FDIC gives domestic depositors priority in any resolution, uninsured depositors and shareholders may suffer losses since the FDIC resolution is not primarily concerned with recovering assets for those groups.

The treatment of bank failures is attributed to their "special" nature that is related to their role in providing a convenient means of payment and the provisioning of credit (Corrigan 1983). Additionally, the presumed contagious nature of bank failures is often cited as something that exacerbates macroeconomic problems (Kaufman 1994). In United States history, banks have been chartered either by Congress directly or through a federal banking agency, by special or general acts of state legislatures, or they have been unchartered or private banks. In their brief history of bankruptcy in the United States, Bliss and Kaufman note that it is with the National Banking Act of 1864 that a federal 
regulatory agency, the Office of the Comptroller of the Currency (OCC), is given the authority to both charter and, if necessary, declare insolvency of a national bank and appoint and direct the actions of the receiver. Though Bliss and Kaufman state that since the early nineteenth century there had been numerous attempts in Congress to provide special bankruptcy treatment for nationally or state-chartered banks, it was not until 1898 that Congress enacted a permanent bankruptcy code and law that specifically exempted both national and state chartered banks (Bliss and Kaufman 2006, p. 45).

Grossman (2007) provides a detailed examination of the evolution of banking structure in the United States and several European countries, including the United Kingdom. According to Grossman, whether countries regulate banks with special banking codes or allow banks to be established under general corporation law depends upon when the central bank was established. Those countries that did not establish central banks but rather relied on commercial banks for currency developed banking codes early (Grossman 2007, p. 196). He notes that the United Kingdom enacted both note centralization and a banking code in 1844, but the Joint Stock Banking Act was repealed 13 years later and, in general, banks are subject to the same regulation as other companies (Grossman 2007, p. 198). The United States establishment of banking codes fits into Grossman’s explanation since federal banking codes were established during the Civil War and therefore prior to the creation of the Federal Reserve System in 1914. This paper seeks to examine the period between the 1791 and 1864 to explain why the United States system came to treat banks differently from other corporations. 
Though the United States is not alone in the world in its special treatment of bank failures, it does differ from many countries, most notably the United Kingdom. The government chartering of banks that began with the Bank of England was the model for chartering that was followed in the United States, but the two countries diverged in their treatment of bank failure resolution. The publication of an extensive study of banking regulation in the world by Barth, Caprio and Levine (BCL) (2006) enables a more detailed examination of where the United States and the United Kingdom diverge in their treatment of bank failures as well as comparison with other countries. The BCL finding for the world is that greater court involvement in bank failures and resolutions, and conversely a lesser role for bank regulatory agencies, is correlated with a larger financial sector. The United States is an outlier in this regard because of its large financial sector and greater role for regulatory agencies involvement. Since the United States is widely regarded as having an efficient financial system that has aided economic growth, this raises the question of whether there are lessons to be learned from the United States financial history. I argue that the evolution of banking in the United States was unique in that, for most of its early history, state chartered banks provided currency, early bank failures influenced liability insurance programs, and the role of private or unchartered banking was not important prior to the Civil War. This unique history explains why the United States evolved in the manner it did, and why the system in the United States may not necessarily be the best policy recommendation for other countries.

The first section of the paper, drawing upon the work of BCL, will provide a review of world practices on the roles of courts and regulatory agencies in bank failures with a 
focus on a comparison of the United States and the United Kingdom. The financial history of the United States will then be examined to determine those factors that were most important in its bank regulatory history. Finally, observations will be made on lessons for other countries and future policy with regard to nonbank financial firms. I conclude that technological and institutional developments bring into question the need for the special treatment of bank failure resolution.

\section{Court Involvement in Bank Failures Across Countries}

Under the auspices of the World Bank, BCL sent an extensive questionnaire to bank regulatory agencies in over 150 countries and, for the first time, produced a dataset on the regulatory structures of countries in the world. What is clear is that countries vary greatly in terms of activities permitted by institutions, ownership restrictions, whether the central bank or another agency is the primary regulator, and the resolution of bank failures. For example, China does not treat banks differently from other firms with regard to the resolution of insolvency. In the United States, under Chapter 11 of the Bankruptcy Code, the debtor-in-possession and the creditor's committees typically play the most important role in corporate failures (Macey, Miller and Carnell 2000).

Though the data enables correlations to be identified and regressions to be done, this does not imply a best practice that could work for all countries. Indeed, the conclusion of BCL is that what is needed is an understanding of the history and institutional structure of a country to understand why a particular structure works in a specific country. In the United States, we are used to a system where the regulatory agencies make the primary 
decisions affecting the failure of financial institutions, and the courts play a secondary role. This is unusual, though not unique, when one examines the experience of other countries.

BCL create an index to measure the degree to which the court system is involved in banking regulation. The index is based on whether or not court approval is required for supervisory actions, such as superceding shareholder rights, removing and replacing management, removing and replacing director, or license revocation; whether a court order is required to appoint a receiver/liquidator in the event of liquidation; and whether the bank shareholders can appeal to the court against a decision of the bank supervisor. Table 1 summarizes the data collected from the 2004 World Bank Survey of Bank Regulation and Supervision. In order to construct the index, BCL divides the degree of court involvement into three areas: management, restructuring and liquidation. 
Table 1: BCL Index for the role of the court system in bank failures

\begin{tabular}{|c|c|}
\hline $\begin{array}{l}\text { Degree to which the court involved in } \\
\text { appointing management }\end{array}$ & $\begin{array}{l}\text { Dummy variable: one indicates the court can } \\
\text { legally declare - such that this declaration } \\
\text { supersedes some of the rights of shareholders - } \\
\text { that a bank is insolvent, and zero otherwise. } \\
\text { Dummy variable: one indicates the court has } \\
\text { authority to intervene in a problem bank } \\
\text { according to the Banking Law, and zero } \\
\text { otherwise. } \\
\text { Dummy variable: one indicates court approval is } \\
\text { required for supervisory actions, such as } \\
\text { superseding shareholder rights, removing and } \\
\text { replacing management, removing and replacing } \\
\text { director, or license revocation, and zero } \\
\text { otherwise. } \\
\text { Dummy variable: one indicates the bank } \\
\text { shareholders can appeal to the court against a } \\
\text { decision of the bank supervisor, and zero } \\
\text { otherwise. }\end{array}$ \\
\hline $\begin{array}{l}\text { Degree to which the court involved in bank } \\
\text { restructuring }\end{array}$ & $\begin{array}{l}\text { Dummy variable: one indicates the court can } \\
\text { supersede shareholder rights regarding bank } \\
\text { restructuring and reorganization, and zero } \\
\text { otherwise. } \\
\text { Dummy variable: one indicates the court can } \\
\text { remove and replace management, and zero } \\
\text { otherwise. } \\
\text { Dummy variable: one indicates the court can } \\
\text { remove and replace directors, and zero otherwise. }\end{array}$ \\
\hline $\begin{array}{l}\text { Degree to which the court involved in bank } \\
\text { liquidation }\end{array}$ & $\begin{array}{l}\text { Dummy variable: one indicates the court is } \\
\text { responsible for appointing a receiver/liquidator in } \\
\text { the event of liquidation, and zero otherwise. } \\
\text { Dummy variable: one indicates court order is } \\
\text { required to appoint a receiver/liquidator in the } \\
\text { event of liquidation, and zero otherwise. }\end{array}$ \\
\hline
\end{tabular}

Source: BCL 2005. 
The index runs from 0 to 9 , with the higher values indicating that the court is more involved in supervisory decisions. BCL find that this index is positively correlated with bank assets relative to GDP; hence, the greater the court involvement, the larger is the banking sector as measured by total assets relative to GDP. Consider one question: is court approval required for supervisory actions, such as superseding shareholder rights, removing and replacing management, removing and replacing director, or license revocation? The answer is yes for 129 countries and no for 20, but the latter includes both the United States and United Kingdom. With regard to whether a court order is required to appoint a receiver/liquidator in the event of liquidation, the results are mixed, with 78 yes and 69 no. However, in the United States, a court order is not required, but it is required in the United Kingdom. Finally, can the bank shareholders appeal to the court against a decision of the bank supervisor? The answer is yes in only 22 countries and no for 127. The United States and the United Kingdom are again split, with the United Kingdom being in the affirmative category (shareholders can appeal to the court), whereas in the United States they cannot (BCL 2006, p. 128).

Countries with a high degree of court involvement (index 7 or greater) include: Algeria, Argentina, Austria, Australia, Belgium, El Salvador, Estonia, Greece, Hong Kong, Israel, Kuwait, Latvia, South Africa, the United Kingdom, and Zimbabwe. What is similar about these countries? Why do these countries have a high degree of court involvement? Do these countries have liberal economic regimes? One thing that might impact this index is whether banks are involved in a greater array of activities; however, this does not imply laissez faire banking. 
Consider the list of countries with low court involvement (0 or 1 index): Brazil, Bulgaria, Chile, Denmark, Korea, Malta, New Zealand, Nicaragua, Panama, Peru, the Philippines, Portugal, Oman, Saudi Arabia, Spain, Taiwan, Thailand, Turkey, Uruguay, the United States and Venezuela, Again, one is hard pressed to explain what these countries have in common that would account for low court involvement in bank resolution. Though it is not possible in this paper to compare all countries, it is interesting that the United States and the United Kingdom are on opposite ends of the spectrum.

\section{A Comparison of the United States and the United Kingdom}

Divergences between the United States and the United Kingdom are of particular interest because the United States system presumably adopted some aspects of the British system. While the above discussion provides some indication of a divergence between the United States and the United Kingdom, further insight is obtained from the questionnaire details. 
Table 2: A Comparison of United States and United Kingdom Banking Supervision

\begin{tabular}{|l|l|l|}
\hline Supervisory Question & U. S. & U. K. \\
\hline $\begin{array}{l}\text { The court can legally declare - such that this declaration } \\
\text { supersedes some of the rights of shareholders - that a bank is } \\
\text { insolvent. }\end{array}$ & No & Yes \\
\hline $\begin{array}{l}\text { The court has authority to intervene in a problem bank, according } \\
\text { to the Banking Law. }\end{array}$ & No & Yes \\
\hline $\begin{array}{l}\text { The court can supersede shareholder rights regarding bank } \\
\text { restructuring and reorganization. }\end{array}$ & No & Yes \\
\hline $\begin{array}{l}\text { The court can remove and replace directors. } \\
\text { The court is responsible for appointing a receiver/liquidator in the } \\
\text { event of liquidation. }\end{array}$ & No & Yes \\
\hline $\begin{array}{l}\text { Court approval is required for supervisory actions, such as } \\
\text { superseding shareholder rights, removing and replacing } \\
\text { management, removing and replacing director, or license } \\
\text { revocation. }\end{array}$ & No & No \\
\hline $\begin{array}{l}\text { Court order is required to appoint a receiver/liquidator in the event } \\
\text { of liquidation }\end{array}$ & No & Yes \\
\hline $\begin{array}{l}\text { The bank shareholders can appeal to the court against a decision of } \\
\text { the bank supervisor }\end{array}$ & No & No \\
\hline \begin{tabular}{l} 
The court can remove and replace management \\
\hline
\end{tabular} & No & Yes \\
\hline
\end{tabular}

Source: BCL 2005.

It is clear from Table 2 that the United States and the United Kingdom differ significantly in their treatment of bank failure resolution. The only common elements are that court approval is not needed for supervisory actions and the bank shareholders can not appeal a decision of the bank supervisor. If the United States system was modeled after the United Kingdom, why is there such a divergence in the role of the courts and the regulatory agencies in bank failures?

The role of the courts and their interaction with the bank supervisory authorities, and ultimately their effect on the banking sector, are largely unexplored issues, 
according to BCL. Whether courts or regulatory agencies have the greatest involvement in bank failures may depend, among other factors, on the:

(1) Independence of the judiciary from the government,

(2) The ability of the courts to adapt to changing financial conditions, and

(3) The independence of the supervisory agency itself (BCL 2006, pg. 129).

One would likely find a great deal of variance in the world on these three factors. Many countries may have court systems that are not independent of the government in power or have court systems that are not very adaptable for banking regulation. In addition, the degree of independence of the bank regulatory agency, which is typically under the Ministry of Finance, varies considerably. In the United States and the United Kingdom, the supervisory agencies are not independent of the government as both countries have federal deposit insurance. Both court systems, however, are generally independent of the government. BCL note that an understanding of why a country has relied on a system in which the regulatory agencies predominate in bank failures requires an examination of financial history and institutional evolution. This paper will discuss United States history in more detail and leave the examination of the financial history of the United Kingdom and other countries to future research.

\section{Early Banking History in the U.S.}

The focus of this paper is on the factors that led to the establishment of state banking codes that predated the National Banking Acts. There are three major reasons why regulatory agencies dominate in the United States. First, as Grossman (2007) argues, the lack of a permanent central bank in the United States until 1914 meant 
that state chartered banks, which were regulated by special banking laws passed by the respective state legislatures, created paper money. Second, bank failures began early in United States history and state governments responded with bank liability guarantee programs and regulatory agencies. Finally, private (unchartered) banking was never very important quantitatively in the United States in the decades after independence.

When banking began in North America, the banks of Europe were in the hands of individuals, families, and partnerships, as they had been for centuries. The incorporated banks, such as the Bank of England and Riksbank of Sweden, were the exception (Hammond 1957, p. 4). In the North American colonies under british rule in the $18^{\text {th }}$ century, the term "banks" referred to incorporated institutions, issues of bills of credit by colonial governments, and an association of private persons that issued its own bills of credit (or private banking) (Hammond 1957, p. 9). Banking arose in the colonies to a large extent due to the shortage of species (gold, silver). The colonial governments issued paper money in part to meet this demand and also to finance expenditures. In July 1780, the Pennsylvania Bank was formed and was funded by private subscriptions of merchants. Its purpose appears to have been a means of patriotic financing for the Continental Army (Hammond 1957, p. 45). The Continental Congress pledged the faith of the United States to protect those who had lent to the bank from losses and the bank was fully liquidated in 1784 (Hammond 1957, p. 43). However, the ongoing financing needs of the Revolutionary War led the Continental Congress to approve the plan for a 
"national bank." At the end of 1781, the Continental Congress passed an ordinance incorporating it as the President and Company of the Bank of North America. As Hammond notes, this was the first real bank in the modern sense in the United States (Hammond 1957, p. 48-50).

The colonial governments of Connecticut, Rhode Island, Massachusetts, and New York passed legislation that granted special status to the Bank of North America, with regard to monopoly and receipt of notes for payment of taxes (Hammond 1957, p. 51). Massachusetts and New York granted charters of incorporation to the Bank of North America that gave the bank a monopoly for the duration of the Revolutionary War (Hammond 1957, p. 51). The state charters were granted because some questioned the legality of the charter from the Continental Congress. The directors of the Bank of North America further sought and obtained a charter from the Pennsylvania Assembly. These actions in 1781 and 1782 constitute the first bank legislation proper in North America (Hammond 1957, p. 51). An attempt by mostly Quaker merchants in Philadelphia to charter a new bank were quashed when the Bank of North America decided to enlarge its capital and allow these merchants to subscribe (Hammond 1957, p. 52).

Efforts to repeal the Pennsylvania charter of the Bank of North America were successful in 1785 . The loss of the charter meant that there was little chance that the state courts would allow the bank any corporate rights or protection of its shareholders from creditors, even though the bank had charters in New York and 
Massachusetts (Hammond 1957, p. 54). The bank was eventually granted a new charter in April 1786, but with restrictions on its asset size. It was granted the charter for only fourteen years, and a new charter forbade the bank to trade in merchandise or to hold more real estate than was needed for its place of business (Hammond 1957, p. 63). ${ }^{1}$

The second bank in the United States was the Bank of New York, established in 1784. It remained private until chartered by the state in 1791. Beginning in 1790, other states began to charter banks, and by 1800 there were twenty-nine chartered banks in the United States (Hammond 1957, p. 144). As Hammond observes, the banks were more than private institutions because, in addition to granting charters, the states were often shareholders in the institutions. In granting privileges to these institutions, there were expectations that they would serve the public interest (Hammond 1957, p. 67).

\section{Money Creation in the United States}

There is no mention in the Constitution of banking. In fact, many signers of the Constitution and some early presidents believed that banking should be outlawed completely! The Constitution gives Congress the power "to coin money and protect the value thereof." The Treasury operated initially on a species basis--all of its monetary transaction had to be settled in gold or silver coin (Wilson 1992).

\footnotetext{
${ }^{1}$ The bank continued in operation under a different charter until it was absorbed by another institution in 1929.
} 
In 1791, despite no explicit authority granted in the Constitution, the Federal Congress chartered the Bank of the United States (BUS) with a twenty-year charter (Wilson 1992, p. 93). The purpose of the bank was to provide banking services for the United States Treasury and to establish a common currency throughout the United States. This was the beginning of central banking in the United States and a precursor to the establishment of the Federal Reserve System in 1913, but it did not last. The BUS was chartered for twenty years. The BUS served a central banking function by accumulating the notes of the state banks. If presented for redemption, the banknotes were payable in gold. The BUS thus helped stabilize the value of the various banknotes of private banks. The BUS would accumulate the private banknotes and thus help reduce the over issue of private banknotes. If a private bank issued more banknotes than it could redeem in gold, then its continued operation would be threatened. In this way, the BUS served a central banking function in limiting and regulating competition. The private banks, for their part, were not necessarily happy about this since it placed a constraint on their creation of money. Thus beginning in the early years of the United States, the federal government was involved in banking (Wilson 1992, p. 70).

One political problem for the BUS was that 70 percent of its capital was owned by foreigners. Also, the debate over the legitimacy of the bank was caught up in the federal authority vs. states' rights conflict. The Constitution prohibited the Treasury from creating paper money (but it could issue debt), and some argued that creating a bank by an Act of Congress amounted to the same thing. After the demise of the First Bank of the United States when its charter expired in 1811, there was a brief period without a bank chartered by Congress. The increase in federal government debt as a result of the War of 
1812 provided an impetus to charter the Second Bank of the United States along similar lines as the first, but with more branches. President Andrew Jackson, who was an ardent opponent of banks, vetoed the charter renewal. In 1819 in the famous states' rights court case "McCulloch v Maryland," the Supreme Court ruled that the bank was constitutional (Wilson 1992, pp. 101-102).

The demise of the Second BUS lead to the period known as the "Free Banking Era." The state chartered banks received permission to enter into the banking business from the state legislatures. In turn, the banks purchased state government debt. In this way, the state governments were not in violation of the Constitutional prohibition on the creation of money by states. Initially, banks received charters by a special act of the state legislature. This led to some abuse since there was an incentive to bribe members of the legislature who were allowing the operation of printing presses. Eventually, in the socalled Free Banking Era, anyone was allowed to start a bank with a state charter, provided specified conditions were satisfied. Usually these involved holding a high percentage of state government debt as backing for the banknotes. Remember that those powers not specifically delegated to the Federal government were reserved for the states. States could not create money, but they could charter banks that would then buy state government debt with banknotes. In 1837, the Supreme Court ruled that state banks and the issuing of banknotes were constitutional. The banknotes issued by the state chartered banks were the primary paper currency during the Free Banking Era.

With the large number of banks and the flexible exchange rates between the banknotes, the financial system resembled today's world of floating national currencies. Not 
surprisingly, Gresham's Law held during this time so that one would spend "bad" money (issued by troubled banks) and hold onto good money (issued by creditworthy banks). With the passage of the National Currency Act in 1863 and the National Banking Act of 1864, the federal government began to charter banks that would compete with the state chartered banks. National banks were prohibited from making real estate loans and had to hold 111 percent in federal government debt against the national banknotes. The federal government imposed a 10 percent tax on banknotes issued by private banks, and this provided an incentive for banks to convert from a state to a national charter. The state chartered banks, though ending the issue of banknotes, began at this time to issue checkable deposits, which were not taxed, and thus the state chartered banks remained in business. The national banks also increased the demand for federal government debt.

Though regulated by a bureau of the Treasury (OCC) and guaranteed by the Treasury, private banks issued the banknotes. One other development occurred in the period of the Civil War that is important to mention and that is the creation of Greenbacks. These notes, which were noninterest-bearing debt, were declared legal tender. Legal tender status for money requires that whenever it is presented for payment for goods and services, it must be accepted, otherwise the debt can be considered paid. Congress can declare money legal tender if it wishes. Though the Greenbacks were supposed to be redeemable in gold, this was suspended until 1879.

Another development was that some state chartered banks took on the role earlier taken by the BUS of accumulating the banknotes of other, usually small, country banks, and then presenting them for redemption. The Suffolk Bank in Boston was a prominent 
example of this. It disciplined the creation of money by small banks, but it also helped create a monopoly for the large banks in the issuing of banknotes.

In the 19th century, banks also formed clearinghouses. The initial purpose of clearinghouses was to facilitate the redemption of banknotes held by competing banks. However, during the banking crises prior to the establishment of the Federal Reserve System in 1913, the Clearinghouses also issued currency. Both of these are functions that would have been carried out by a central bank.

The establishment of the Federal Reserve was an attempt to use the clearinghouse idea on a regional and, eventually, national level. Thus, instead of thousands of local clearinghouses, the Federal Reserve established 12 regional clearinghouse banks. Though the federal government placed legal restrictions on the creation of money, and issued paper currency at various times, until the creation of the Federal Reserve System in 1913, there was no exclusive monopoly held by a government central bank on the issuing of paper money. This is quite different from the evolution in most countries at the time.

\section{Bank Failures and the Insurance of Banknotes in the United States.}

The second contributing factor in the unique United States history was that bank failures began early in its history. The first bank failure in the United States was the Farmers Exchange Bank of Glocester, RI in 1809. There was large-scale fraud in the issuing and redeeming of banknotes. This bank failure was cited in the debates over the renewal of the Bank of the United State charter in 1810. Those who held the banknotes in the Farmers Exchange Bank complained to the legislature and the 
legislature imposed a penalty for failure to redeem banknotes at their face value. This dilemma is that the bank that is in trouble will likely have to restrict credit, if it redeems its notes at par. This failure was cited in the debates over the charter of the Second Bank of the United States. In June 1809, the Massachusetts legislature imposed a penalty for refusal of a bank to redeem its notes and this penalty was included in renewal of the Second Bank of the United States charter. Other states soon followed with similar penalties for banks failing to redeem notes or deposits (Hammon 1957, p. 178). The courts upheld these penalties on the grounds that bank notes were similar to promissory notes and thus would be paid (Hammond 1957, p. 179).

The dilemma presented by penalties on redemption of course caused problems because of the implied restriction of credit. In 1819, the Maryland legislature passed legislation against banks that redeemed notes and, two days later, legislation against persons seeking to redeem them (Hammond 1957, p. 180). The source of the problem was the general confusion over whether bank liabilities were debt or money.

The insurance of bank liabilities began in 1829 with the creation of the New York Safety Fund. This is the first insurance fund and the first regulatory agency. Banks were required to report to the banking commission. American legislators for the first time recognized an obligation on the part of the public authorities to protect the creditors of banks, they created a safety fund raised by annual payments and 
established a board of bank commissioners with supervisory and reporting functions.

The Safety Fund was established while Martin Van Buren was governor of New York. In his Autobiography, Van Buren stated that even though he had always been opposed to the multiplication of banks, he did not see a means of stopping their spread, and so shifted his attention to how protect the public against bank failures. Joshua Forman, a lawyer and a founder of the city of Syracuse, New York, submitted a plan to Van Buren to protect the public. It is surmised that Van Buren, in addition to helping the public, also recognized that such a plan would give some political control over the banks (Redlich 1968, p. 89). Forman’s plan was to make all of the banks responsible for any loss to the public from any bank. Forman's goals were to promote good bank management, secure the public against losses from bank failures, and furnish a sound and well-regulated currency (Redlich 1968, p. 90). The essence of the plan was to create a fund from annual payments of member banks and to establish a board of bank commissioners with supervisory and reporting functions (Redlich 1968, p. 91). As Redlich notes, Forman's proposal for bank commissioners to examine banks was merely continuing a tradition already established with the Bank of the United States and banking laws in various states (Redlich 1968, p. 92). The difference in the Forman plan is that the regulatory authority of government was based upon federal or state investment in the bank. Forman's proposal represented a significant evolution in bank regulation by government because it established timely exams by individuals who were 
specifically trained for bank examination (Redlich 1968, p. 92). Following the passage of the legislation in New York, other states soon followed with similar bank examination and regulation laws (Redlich 1968, p. 94-95).

\section{Private Banking in the United States}

Around 1800, the twenty-nine incorporated banks began to complain about the issue of notes by unincorporated competitors. Legislatures began to pass restraining acts against the issuance by unincorporated banks of notes that circulated as money. The problem that arises is, what is money and what is not? There is debate over whether paper money or deposits should be considered money or whether species (gold or silver) is the only money (Hammond 1957, p. 185). Today we recognize this debate as one over the monetary base or the money supply, or inside versus outside money. Then, as now, it affects how banks are treated by the regulatory agencies and the courts. As Hammond notes:

The common law right to borrow was being distinguished from the right to borrow by the issue of obligations intended to circulate as money. The latter was being more and more positively reserved to charter banks. (Hammond 1957, p. 185)

There were three types of credit institutions emerging in this early period. The first were the unincorporated banks (private banks). Second were mutual savings banks and finally insurance companies. It was the liabilities of the private banks that were in direct competition with the liabilities of incorporated banks. However, the liabilities of the private banks were less widely held than those of the incorporated banks (Hammond 1957, p. 193). Because the private banks were unchartered, they were also not susceptible to the same political influences as the chartered banks. 
The generally accepted history of banks in the United States has been that of Hammond (1957, p. 68), who stated that private banking was unimportant in early United States history (prior to 1820), though acknowledging that such unchartered banks existed, but were overall a small percentage of the assets of the banking system. Richard Sylla (1976) presents preliminary evidence that private banking may have been more important than previously supposed. Sylla cites as evidence the reports of bank incorporation for various states at the time that restraining acts were passed which outlawed private banking. The incorporated banks could have been de novo banks, or private banks that then became chartered. For example, between 1810 and 1814, Pennsylvania chartered four banks. However, in 1814, the year restraining legislation was passed, 41 banks were chartered (Sylla 1976, p. 183). Though only a very detailed study would answer his question, Sylla asks whether it is more likely that the banks were true de novos or were already existing private banks. The answer is important because it impinges on the question of the importance of private banking in early United States history. Sylla notes that the only detailed study of private banking in this early period is that of Fritz Redlich (1968).

Though Richard Sylla argues that private banking played a larger role than initially believed in this period, it is really only later that private banking becomes important. Banknotes of unincorporated institutions were prohibited, but deposits were not. Sylla suggests that private banking could have had a greater role than 
previously believed, especially in the period after the 1820s. Though private banking may have been larger in the antebellum period, all agree it was small in the earlier period. In the crucial early period of United States history, unchartered banking was rare and did not significantly impact the development of banking laws. Had there been more private banks, and especially ones that failed, this could have changed how bank failures were resolved. However, as already noted, Congress did not pass a permanent bankruptcy law until near the turn of the twentieth century.

\section{Policy Implications}

Should the failure of banks be treated differently from that of other corporations? This has been the case in the United States, but it is not clear that it is the best policy recommendation for all countries at all times. The United States evolved in a very special set of circumstances. The lack of a true central bank with a common currency, early bank failures, and the lack of private banking were unique. No other country faced all of these circumstances. The United States system, though nominally modeled after the United Kingdom, evolved very differently because of United States institutions.

As BCL note, politics influence the design of a regulatory structure. The institutions may be efficient and promote economic growth, or inefficient and retard economic growth. Though the United States financial history is complex, a set of institutions has evolved that promote long-term economic growth. Whether 
these institutions remain appropriate in a period of rapidly changing technology and globalization remains an open question.

A further development that is due to rapid technological change and institutional reform is the blurring of the lines between banks and nonbanks. Will failures by nonbank financial firms continue to be handled by the courts in the United States, or will the financial regulatory agencies become involved? Banks face competition in the payments system from Paypal and other means of payment through the Internet and competition on the lending from a myriad of credit firms. Such competition with banks will continue and the policy question that will arise is whether the failure of institutions that compete with banks should also be treated as "special." In the United States, this could lead to an expansion of the role of financial regulatory agencies such as the Federal Reserve System in regulating and supervising nonbank firms. Alternately, as banks lose their special nature, courts could play a larger role in bank failures, thus putting financial institutions on par with other corporations. 


\section{References:}

Barth, James R., Gerard Caprio, and Ross Levine. 2006. Rethinking Bank Regulation: Till Angels Govern. Cambridge: Cambridge University Press.

Bliss, Robert R. and George G. Kaufman. 2006. “A Comparison of United States Corporate and Bank Insolvency Resolution,” Federal Reserve Bank of Chicago Economic Perspectives, 2nd Quarter, v. 30, iss. 2, pp. 44-56

Corrigan, E. Gerald. 1983. “Are Banks Special?,” 1982 Annual Report, Federal Reserve Bank of Minneapolis.

Grossman, Richard S. 2007. (R)evolution in Banking: The Development of Commercial Banking in the Industrialized World, 1800-2000. Unpublished manuscript.

Hammond, Bray. 1957. Banks and Politics in America from the Revolution to the Civil War. Princeton: Princeton University Press.

Hupkes, Eva. 2000. The Legal Aspects of Bank Insolvency. The Hague, Netherlands: Kluwer.

Kaufman, George G. 1994. "Bank Contagion: A Review of the Theory and Evidence," Journal of Financial Services Research, April, v. 8, iss. 2, pp. 123-50.

Macey, Jonathan R., Geoffrey P. Miller, and Richard Scott Carnell. 2001. Banking Law and Regulation. Gaithersburg and New York: Aspen Law and Business.

Redlich, Fritz. 1968. The Molding of American Banking. New York and London: Johnson Reprint Corporation.

Swire, Peter P. 1992. "Bank Insolvency Law Now that It Matters Again,” Duke Law Journal, Vol. 42, No. 3, pp. 469-556.

Sylla, Richard. 1976. "Forgotten Men of Money: Private Bankers in Early United States History,” Journal of Economic History, 36(1): 173-188.

Todd, Walker. 1994. "Bank Receivership and Conservatorship,” Economic Commentary, Federal Reserve Bank of Cleveland, October 1.

Wilson, Thomas. 1992. The Power “To Coin” Money: The Exercise of Monetary Powers by the Congress. Armonk, NY: M.E. Sharpe. 